\title{
Wood properties of black spruce (Picea mariana (Mill.) BSP) in relation to ring width and tree height in even- and uneven-aged boreal stands
}

\author{
Émilie Pamerleau-Couture ${ }^{1} \cdot$ Sergio Rossi ${ }^{1,2} \cdot$ David Pothier $^{3} \cdot$ Cornelia Krause $^{1}$
}

Received: 17 October 2018 / Accepted: 27 March 2019 / Published online: 25 April 2019

(C) INRA and Springer-Verlag France SAS, part of Springer Nature 2019

\begin{abstract}
- KeyMessage Wood properties were generally similar in unmanaged even-aged and uneven-aged black spruce stands. In contrast, in managed forests, wood density was higher in even-aged than in uneven-aged stands. As ring width is the discriminant factor, forest management should regulate the intensity of partial cutting to maintain a high wood density. - Context North American boreal forests experience recurrent disturbances, such as fire and insect outbreaks, that shape the structure of even-aged and uneven-aged stands. Ecosystem-based forest management practices, such as partial cutting, aim to increase timber yields, and these forest harvesting approaches are being applied more frequently. Although the influence of these practices on tree growth is well known, few studies have examined their impact on anatomy and density of the resulting wood. - Aim This research studied the relationships between wood properties and ring width and tree heights in even- and uneven-aged black spruce (Picea mariana (Mill.) BSP) stands and how these relationships are modified following partial cutting.

- Method Wood density (ring, earlywood, latewood, and maximum density) and anatomical traits (lumen area, cell-wall thickness, and tracheid length) were measured at breast height on the stem of black spruce trees. The measured wood properties were then correlated with ring width and stem height.

- Results The model demonstrated significant correlations between most measured wood parameters and ring width with only small differences between even- and uneven-aged unmanaged stands. Five wood properties were influenced by tree height in even-aged and uneven-aged unmanaged plots. Partial cutting increased the number of significant relationships between wood properties (ring, latewood, maximum density, early- and latewood lumen area, tracheid length) and tree height. We detected differences in wood properties between even- and uneven-aged plots. Although we detected no change in average ring density, the variation of intra-annual density increased, due to changes in earlywood and latewood density that resulted in more heterogeneous rings.

- Conclusion Partial cutting should take into consideration the age structure of the stand when the density of wood products matters.
\end{abstract}

Keywords Wood properties · Managed and unmanaged forest · Even- and uneven-aged forest · Picea mariana · Wood density · Wood anatomy

Handling Editor: Erwin Dreyer

Sergio Rossi

sergio.rossi@uqac.ca

Émilie Pamerleau-Couture

epamerleau@hotmail.com

David Pothier

david.pothier@sbf.ulaval.ca

Cornelia Krause

cornelia_krause@uqac.ca
1 Département des sciences fondamentales, Université du Québec à Chicoutimi, Québec, Canada

2 Key Laboratory of Vegetation Restoration and Management of Degraded Ecosystems, Guangdong Provincial Key Laboratory of Applied Botany, South China Botanical Garden, Chinese Academy of Sciences, Guangzhou, China

3 Département des sciences du bois et de la forêt, Université Laval, Québec, Canada 


\section{Introduction}

Forestry research converges on tree growth and the factors that influence tree-ring width, given the importance of tree dimensions in determining the economic value of forest products (Liu et al. 2007; Tardif and Bergeron 1993). For example, the importance of spring and summer temperatures and water availability during the growing season has been stressed (Deslauriers et al. 2003). Other studies have focused on the silvicultural practices that improve individual tree growth (e.g., Weetman 1975; Raulier et al. 2003). However, wood properties remain a critical trait for some specific end uses of timber (Alteyrac et al. 2005). The definition of wood property includes a number of wood characteristics and cell features, and the precise definition depends on the specific requirements for the end products. Wood with high mechanical resistance is sought for construction, whereas fiber length is important for pulp and paper (Shmulsky and Jones 2011).

Wood density is one of the main factors affecting wood quality, as this parameter is related to mechanical properties, and a good indicator of the yield and quality of pulp (Saranpää 2003; Shmulsky and Jones 2011). Wood density, which in conifers culminates in the latewood, is controlled by cell traits such as cell-wall thickness and lumen area (Raven et al. 2000; Saranpää 2003; Shmulsky and Jones 2011). Also tracheid length has a considerable influence on wood quality, especially for specific products such as paper, as it improves tear resistance (Shmulsky and Jones 2011). Ring width is related to the radial number of cells produced during the growing season, whereas cell dimensions retain a marginal role (Rossi et al. 2011).

The relationships between tree-ring width and wood properties are well known. Latewood ring width in conifers remains relatively constant despite the variability in total ring width (Shmulsky and Jones 2011; Wang et al. 2002). Thus, larger tree rings with a smaller proportion of latewood display a smaller density (Xiang et al. 2014). In many boreal tree species, larger tree rings are associated with smaller tracheids (Dutilleul et al. 1998; Mäkinen et al. 2002a; Shmulsky and Jones 2011).

Two stand structures characterize boreal forest ecosystems: even-aged and uneven-aged. The first occurs by the prompt germination of aerial seeds released by semi-serotinous cones after intensive fire events (Bouchard et al. 2008; St-Pierre et al. 1991). In the absence of other intense disturbances that could again kill the entire stand, or in cases where the firereturn interval exceeds the tree life span, stands are affected by smaller scale, secondary disturbances (Boucher et al. 2003; Côté et al. 2010). The gap dynamics related to small-scale disturbances represent the main regulator of stand structure and tree growth in uneven-aged forests (Harper et al. 2006; Pham et al. 2004; Rossi et al. 2009).
In even-aged stands, the typical tree-ring pattern is a decreasing trend in width from pith to bark, associated with a gradual increase in wood density (Piispanen et al. 2014). Trees of uneven-aged stands display a more variable ring-width profile depending on the length and severity of tree suppression (Piispanen et al. 2014; Pretzsch and Rais 2016). Thus, uneven-aged stands should display trees with variable wood characteristics. Torquato et al. (2014) found lower mechanical wood properties in trees within uneven-aged forests, which was not explained by wood density. Other processes, such as light compression wood formation or layer origin of the individuals, may distinguish the two stand structures (Torquato et al. 2014).

Mature black spruce trees are taller in even- than in unevenaged stands (Pamerleau-Couture et al. 2015), when favorable growing conditions are present after fire and in absence of competition with ground vegetation (Philip 1994). In unevenaged stands, this species can survive more than 100 years in the understory under conditions of low light intensity (Rossi et al. 2009; Viereck and Johnston 1990). Poor growing conditions in the understory explain the lower height and diameter and the older ages of black spruce in uneven-aged stands (Claveau et al. 2002; Rossi et al. 2009). Tree height is another important predictor for wood traits (Lenz et al. 2014). Auxin accelerates cell differentiation, thereby limiting the time for cell enlargement (Aloni and Zimmermann 1983; Anfodillo et al. 2012). As the auxin concentration is higher near the apex of the tree (Lovisolo et al. 2002), tracheid diameter increases downward along the stem (Anfodillo et al. 2006). Thus, cell-lumen areas are wider in the taller trees of even-aged stands compared to the smaller trees of uneven-aged stands.

Various forms of partial cuttings are now applied in North American forests (Bergeron et al. 1999; Hunter 1990). Commercial thinning, a partial-cutting approach that reduces stand density by targeting specific residual trees, can improve radial growth in even-aged stands (Pamerleau-Couture et al. 2015; Vincent et al. 2009). Partial cutting can change the microclimatic conditions around the remaining trees, and possibly modify the properties of the xylem cells. Increases in water availability can produce larger cell lumens (Fernandez et al. 2012), as the tracheid dimension is a function of tree-water status at the time of cell formation (Fonti and Jansen 2012). Partial cuttings are also applied increasingly in uneven-aged stands, and with higher intensities than in even-aged stands. Consequently, the relationship between ring width and wood properties could vary according to the stand structure. The relationships between ring width and wood properties of boreal species have been described for even-aged stands (e.g., Alteyrac et al. 2005; Koubaa et al. 2000; Krause et al. 2011), but remains basically unknown for uneven-aged stands.

Despite its economic importance, wood quality is often overlooked in forestry management due to a lack of knowledge as well as the time-consuming and costly evaluation of wood traits (Lenz et al. 2014). Nonetheless, a relationship 
between wood properties and tree-ring width and tree height could serve as a proxy for large-scale assessment of wood quality. This baseline information is not yet available for black spruce, the most widespread and economically important tree species in Canada (Zhang and Koubaa 2008). In this study, we evaluated the relationship between wood properties and treering width and stem height of mature black spruce from evenand uneven-aged stands subjected to partial cutting. We raise the hypothesis that the relationships between wood properties and tree-ring width and tree height (1) were stronger in evenaged than uneven-aged stands, and (2) were altered by the partial cutting.

\section{Methods}

\subsection{Study area and experimental design}

The study area is located in the Saguenay-Lac-St-Jean region, QC, Canada, within the area of $47^{\circ} 51^{\prime}$ to $50^{\circ} 25^{\prime} \mathrm{N}$ and $70^{\circ}$ $13^{\prime}$ to $72^{\circ} 11^{\prime} \mathrm{W}$. In May, the period of cambium reactivation, the average temperature is $10.1{ }^{\circ} \mathrm{C}(1981-2010)$. In June and July, the period of maximal cambial activity, the average temperature is $17.4^{\circ} \mathrm{C}$. Average annual precipitation is $980 \mathrm{~mm}$. The sites are dominated by black spruce (Picea mariana (Mill.) BSP) growing within in the balsam fir-yellow birch and balsam fir-white birch domains.

We collected wood samples from ten pairs of plots (one unmanaged and one managed per pair). Each unmanaged plot was located within $1 \mathrm{~km}$ from a managed plot. To limit environmental variation between plots, we selected sites having a gentle slope and adequate drainage. Black spruce basal area represented at least $50 \%$ of the total basal area. The partial cuttings had been applied at least 5 years prior to sampling, occurring between 2008 and 2011. Two different partialcutting treatments were applied: (i) in even-aged plots, commercial thinning from below (CT) removed $35 \%$ of the basal area, which means the removal of trees having smaller diameters (Doucet et al. 2009); and (ii) in uneven-aged plots, a diameter-limit cutting practice removed all trees having a diameter at breast height $>14 \mathrm{~cm}(70 \%$ basal area removal). Partial cuttings resulted in similar reductions (52.6-53.5\%) in stand density between even-aged and uneven-aged plots (Pamerleau-Couture et al. 2015). No anthropogenic disturbances occurred in the unmanaged plots.

\subsection{Tree selection}

In each selected plot, we sampled five individuals. We sampled a total of 25 trees per stand structure (even- and unevenaged stands; Table 1). In the unmanaged plots, trees were randomly selected. In the managed plots, trees were randomly selected based on a positive radial growth following partial cutting (at least $20 \%$ post-cutting annual growth (at $0.2-\mathrm{m}$ height)) compared to a 10-year pre-partial cutting period (Vincent et al. 2009). This selection method allowed us to evaluate the relationship between ring width and wood quality characteristics in actively growing trees, although this did prevent us from drawing general conclusions regarding the effect of partial cutting on wood quality.

Selected trees were felled, and we removed wood disks at the base of the stem to assess the exact tree age. We recorded tree-ring width, wood density, and cell parameters at $1.3-\mathrm{m}$ stem height. We measured tree height and crown length in the field. We excluded five trees (three from unmanaged and two from managed plots) from the analysis because of identification errors or the presence of knots.

\subsection{Wood quality measurements}

We recorded wood density, lumen area, cell-wall thickness, and tracheid length. We determined the years used for wood density measurements based on the year of the partial cutting (years 1 to 8 post-cutting) in the managed plots (Fig. 1). For the unmanaged plots, the sampled rings were from the same calendar years than the associated managed plot to minimize any weather/climate effects. We measured anatomical properties beginning from year 3 post-cutting (years 3 to 8). Years 1 and 2 were excluded because the positive growth response of black spruce begins at the third year after cutting (Vincent et al. 2009). In the case of tracheid length, only years 3 to 6 were analyzed due to the time-consuming nature of this process (Fig. 1).
Table 1 Mean \pm standard deviation, minimum and maximum diameter at $1.3 \mathrm{~m}$ (DBH), age, height, and crown ratio, for $n$ trees in uneven- and even-aged plots for both unmanaged and managed stands

\begin{tabular}{llllll}
\hline & Unmanaged & & & Managed \\
\cline { 2 - 3 } \cline { 5 - 6 } & Uneven-aged $(n=24)$ & Even-aged $(n=23)$ & & Uneven-aged $(n=23)$ & Even-aged $(n=25)$ \\
\hline DBH $(\mathrm{cm})$ & $11.6 \pm 2.6$ & $16.0 \pm 3.3$ & & $10.6 \pm 3.2$ & $17.2 \pm 3.3$ \\
Age (years) & $127 \pm 33$ & $102 \pm 40$ & $98 \pm 16$ & $80 \pm 19$ \\
Height (m) & $9.4 \pm 1.8$ & $14.9 \pm 2.9$ & & $7.6 \pm 2.5$ & $14.6 \pm 3.2$ \\
Crown ratio & $0.54 \pm 0.15$ & $0.41 \pm 0.16$ & & $0.69 \pm 0.15$ & $0.59 \pm 0.13$ \\
\hline
\end{tabular}

Crown ratio $=$ crown length $/$ tree height 


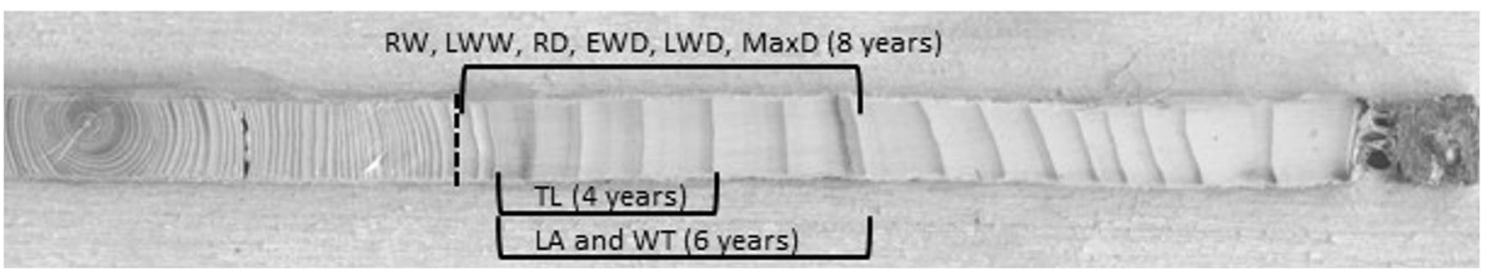

Fig. 1 Schematic representation of the wood-quality measurements. Vertical dotted line represents the year of the partial cutting. Horizontal lines indicate the number and emplacement of the measured rings for the different wood characteristics. Eight years were measured to determine ring width (RW), latewood width (LWW), ring density (RD), earlywood density (EWD), latewood density (LWD), and maximum density (MaxD). Four years were measured to determine tracheid length (TL). Six years were measured to determine lumen area (LA) and wall thickness (WT)

\subsection{Wood density}

We collected 1.7-mm-thick (longitudinal) and 25-mmwide (tangential) wood strips at $1.3-\mathrm{m}$ stem height. Wood sections were then placed in a cyclohexane/ ethanol (2:1) solution for $24 \mathrm{~h}$ and then in hot water for a further $24 \mathrm{~h}$. The wood samples were then dried to a $12 \%$ moisture content in a conditioning room under controlled conditions of $20{ }^{\circ} \mathrm{C}$ and $65 \%$ relative humidity (Alteyrac et al. 2006). We measured ring width (RW), latewood width (LWW), average ring density (RD), earlywood density (EWD), latewood density (LWD), and maximum density (MaxD) from bark to pith using an Xray densitometer (QTRS-01X Tree Ring Analyser; QMS Inc., Knoxville, TN). We analyzed only the years following the partial cuttings to compare with the other datasets (Fig. 1). We applied the maximum derivative method with a six-degree polynomial to detect the transition between earlywood and latewood (Koubaa et al. 2002)

\subsection{Tracheid properties}

We measured the lumen area and cell-wall thickness at 1.3-m stem height. We embedded thin transverse sections in paraffin, cut with a rotary microtome into $8-10-\mu m$-thick sections, fixed with albumin and colored with safranin (Deslauriers 1999). We measured cell-wall thickness (WT) and lumen area (LA) with a WinCELL image analysis system along three radial paths, standardized and averaged for each tree (Deslauriers et al. 2003; Krause et al. 2010; Vaganov 1990). We distinguished between earlywood and latewood using Mork's procedure, which consists of defining a cell as latewood when the lumen area is less than twice the thickness of a double cell wall (Denne 1988).

Using the same wood section as for the anatomical measurements, we prepared another sample $(1.5-\mathrm{cm}$ thick) to allow a manual separation and maceration of tree rings in a solution of equal volume glacial acetic acid and hydrogen peroxide and then heated at $60{ }^{\circ} \mathrm{C}$ for $24 \mathrm{~h}$ (Franklin 1945). The resulting suspension was rinsed with distilled water and then shaken for $30-45 \mathrm{~s}$ to obtain a homogeneous separation of the fibers. For each sampled year, we measured the length of 5000 tracheids using a fiber tester (Lorentsen \& Wettre, Kiste, Sweden). We used the weight-weighted mean fiber length as it reduced the potential impact of fines and gave more weight to the fibers in the length determination (Bouslimi et al. 2014).

\subsection{Statistical analysis}

The wood-quality measurements were calculated for earlywood, latewood, and the entire tree ring. General linear models (GLM) correlated tree-ring width and tree height with xylem traits and wood properties, using stand structure (even- and uneven-aged) as a categorical variable. GLMs were applied separately for unmanaged and managed plots. We ran the models using the GLM procedure in SAS (SAS Institute Inc., Cary, NC). For all analyses, we used the average measurement of each wood quality trait for the recorded years. When required, data were logtransformed to linearize the relationships and satisfy the assumptions of normality and homogeneity of variance.

\section{Results}

\subsection{Tree characteristics}

Tree age across all uneven- and even-aged stands in both the unmanaged and managed plots ranged between 80 and 127 years (Table 1). Trees in the even-aged stands were taller and larger compared to the trees in the uneven-aged stands. The height difference between stands reached $48 \%$ in the managed plots and $37 \%$ in the unmanaged plots.

For managed stands, all wood property values were higher in the even-aged than in the uneven-aged plots (Table 2). Lumen area in early- and latewood, ring width, and tracheid length were all $19 \%$ higher in the even-aged trees compared to the uneven-aged trees in managed plots. Also, in the managed 
Table 2 Mean \pm standard deviation of wood characteristics in uneven- and even-aged plots for both unmanaged and managed stands. The statistical differences between treatments are reported in Table 3

\begin{tabular}{|c|c|c|c|c|c|}
\hline & & Unmanaged & & Managed & \\
\hline \multicolumn{2}{|l|}{ Wood characteristic } & Uneven-aged & Even-aged & Uneven-aged & Even-aged \\
\hline \multirow[t]{4}{*}{ Wood density $\left(\mathrm{kg} \mathrm{m}^{-3}\right)$} & Ring & $451.5 \pm 30.9$ & $459.3 \pm 49.8$ & $430.3 \pm 34.0$ & $445.8 \pm 34.4$ \\
\hline & Earlywood & $402.5 \pm 36.7$ & $402.1 \pm 36.6$ & $374.1 \pm 25.6$ & $382.3 \pm 26.7$ \\
\hline & Latewood & $621.1 \pm 101.4$ & $610.0 \pm 123.1$ & $575.6 \pm 76.3$ & $639.3 \pm 76.3$ \\
\hline & Maximum & $664.9 \pm 116.7$ & $660.5 \pm 148.4$ & $632.3 \pm 98.4$ & $703.0 \pm 97.3$ \\
\hline Latewood (\%) & Ring & $31.3 \pm 11.5$ & $34.4 \pm 12.9$ & $33.1 \pm 80.0$ & $29.0 \pm 10.3$ \\
\hline \multirow[t]{2}{*}{ Width (mm) } & Ring & $0.51 \pm 0.28$ & $0.52 \pm 0.27$ & $0.65 \pm 0.43$ & $0.80 \pm 0.38$ \\
\hline & Latewood & $0.14 \pm 0.05$ & $0.16 \pm 0.06$ & $0.19 \pm 0.09$ & $0.20 \pm 0.07$ \\
\hline \multirow[t]{2}{*}{ Lumen area $\left(u^{2}\right)$} & Earlywood & $475.3 \pm 86.7$ & $551.0 \pm 114.5$ & $416.5 \pm 63.9$ & $600.3 \pm 72.2$ \\
\hline & Latewood & $83.2 \pm 20.9$ & $92.5 \pm 19.5$ & $86.0 \pm 24.1$ & $109.1 \pm 20.8$ \\
\hline \multirow[t]{2}{*}{ Wall thickness (um) } & Earlywood & $2.33 \pm 0.31$ & $2.22 \pm 0.30$ & $2.19 \pm 0.28$ & $2.30 \pm 0.21$ \\
\hline & Latewood & $4.02 \pm 0.34$ & $3.71 \pm 067$ & $4.03 \pm 0.46$ & $4.13 \pm 0.50$ \\
\hline Tracheid length (mm) & Ring & $2.75 \pm 0.30$ & $2.99 \pm 0.29$ & $2.36 \pm 0.29$ & $2.93 \pm 0.28$ \\
\hline
\end{tabular}

plots, latewood and maximum wood density were $10 \%$ higher in the even-aged trees relative to the uneven-aged trees. Latewood width, as well as lumen area in both earlywood and latewood, was $10 \%$ higher in the unmanaged even-aged trees than in the unmanaged uneven-aged plots (Table 2).

\subsection{Unmanaged plots}

The linear model revealed significant correlations between the measured wood parameters and tree-ring width $(p<0.002)$, except for ring wood density and earlywood cell-wall thickness (Table 3). Furthermore, the relationships between wood properties and tree-ring width were similar for trees in evenaged and uneven-aged plots (Table 3 ). However, the values of two parameters, earlywood lumen area $(p<0.05)$ and tracheid length $(p<0.05)$, were smaller for trees in uneven-aged plots than those in even-aged plots.

We observed a relationship between ring width and earlywood as well as latewood density (Fig. 2). For both stand types, earlywood density decreased while latewood and maximum density increased with increasing tree-ring width. Furthermore, maximum density $\left(R^{2}=0.6\right)$ and latewood width $\left(R^{2}=0.57\right)$ increased with tree-ring width (Fig. 2). Tracheid length and the lumen area in earlywood and latewood were less tightly correlated with ring width $\left(R^{2}=0.31\right.$, $R^{2}=0.39$, and $R^{2}=0.39$, respectively).

Tree height influenced significantly five of the ten measured wood parameters: ring wood density $(p<0.01)$, earlywood density $(p<0.05)$, tracheid length $(p<0.01)$, and cellwall thickness in both earlywood $(p<0.05)$ and latewood $(p<$ 0.05 ) (Table 3 ). Using the linear model to determine the relationship between wood properties and tree height, we observed significant differences between uneven-aged and even-aged stands in terms of ring density $(p<0.05)$, earlywood density $(p<0.05)$, and earlywood lumen area $(p<0.01)$
(Fig. 3, Table 3). Ring density and earlywood density increased for even-aged trees as tree height increased, whereas there was no clear trend for uneven-aged trees (Fig. 3). In an inverse relationship, the lumen area of the even-aged trees decreased as tree height increased.

\subsection{Managed plots}

In the managed plots, most wood properties - except ring wood density, earlywood density, and tracheid length - were correlated with tree-ring width $(p<0.0001$; Table 3$)$. Lumen area in earlywood $(p<0.0001)$ and latewood $(p<0.0001)$, as well as tracheid length $(p<0.0001)$, differed significantly between even-aged and uneven-aged stands in regard to tree-ring width (Table 3). Earlywood and latewood lumen area increased as tree-ring width increased in uneven-aged trees, whereas these two parameters showed less variation with treering width for the even-aged stands. Tracheid length was longer in even-aged stands compared to uneven-aged stands at similar tree-ring widths.

Tree height influenced six wood properties: ring wood density $(p<0.05)$, latewood density $(p<0.01)$, maximum density $(p<0.01)$, earlywood ( $p<0.0001)$, and latewood lumen area $(p<0.05)$, as well as tracheid length $(p<$ 0.0001) (Table 3). Comparing even- and uneven-aged stands, the linear model revealed significant differences with regard to tree height between earlywood ( $p<$ $0.0001)$ and latewood lumen area $(p<0.05)$, earlywood cell-wall thickness $(p<0.05)$, and tracheid length $(p<$ 0.05 ) (Table 3 ). Earlywood and latewood lumen area of uneven-aged trees increased with tree height (Fig. 5), whereas an opposite pattern was observed for even-aged trees. Uneven-aged trees had lower values for cell-wall thickness and tracheid length than even-aged trees measured at similar tree heights. 
Table 3 Generalized linear model analysis on black spruce wood properties showing the relation with ring width (RW) and tree height
$(\mathrm{H})$, within two types of stand structure ( $\mathrm{T}$ - even-aged and uneven-aged) in unmanaged plots.

\begin{tabular}{|c|c|c|c|c|c|c|c|c|c|c|c|c|c|}
\hline \multirow[b]{2}{*}{ Factor } & & \multicolumn{6}{|c|}{ Unmanaged } & \multicolumn{6}{|c|}{ Managed } \\
\hline & & Source & $F$ & $P$ & Source & $F$ & $P$ & Source & $F$ & $P$ & Source & $F$ & $P$ \\
\hline \multirow[t]{12}{*}{ Wood density } & Ring & RW & 1.61 & 0.2120 & $\mathrm{H}$ & 9.03 & 0.0044 & RW & 0.76 & 0.3870 & $\mathrm{H}$ & 5.51 & 0.0235 \\
\hline & & $\mathrm{T}$ & 0.35 & 0.5598 & $\mathrm{~T}$ & 5.97 & 0.0187 & $\mathrm{~T}$ & 2.00 & 0.1648 & $\mathrm{~T}$ & 0.12 & 0.7340 \\
\hline & & $\mathrm{RW}^{*} \mathrm{~T}$ & 1.82 & 0.1850 & $\mathrm{H}^{* \mathrm{~T}}$ & 3.55 & 0.0662 & $\mathrm{RW}^{*} \mathrm{~T}$ & 3.15 & 0.0830 & $\mathrm{H}^{*} \mathrm{~T}$ & 1.58 & 0.2151 \\
\hline & Earlywood & RW & 23.71 & $<0.0001$ & $\mathrm{H}$ & 4.47 & 0.0403 & RW & 0.88 & 0.3531 & $\mathrm{H}$ & 1.77 & 0.1907 \\
\hline & & $\mathrm{T}$ & 0.09 & 0.7667 & $\mathrm{~T}$ & 6.48 & 0.0146 & $\mathrm{~T}$ & 2.30 & 0.1364 & $\mathrm{~T}$ & 0.00 & 0.9571 \\
\hline & & $\mathrm{RW}^{*} \mathrm{~T}$ & 1.09 & 0.3015 & $\mathrm{H}^{* \mathrm{~T}}$ & 1.10 & 0.2997 & $\mathrm{RW}^{*} \mathrm{~T}$ & 7.75 & 0.0079 & $\mathrm{H}^{*} \mathrm{~T}$ & 1.10 & 0.3009 \\
\hline & Latewood & RW & 52.69 & $<0.0001$ & $\mathrm{H}$ & 0.32 & 0.5724 & RW & 44.93 & $<0.0001$ & $\mathrm{H}$ & 10.25 & 0.0025 \\
\hline & & $\mathrm{T}$ & 1.07 & 0.3063 & $\mathrm{~T}$ & 1.61 & 0.2118 & $\mathrm{~T}$ & 3.08 & 0.0864 & $\mathrm{~T}$ & 0.36 & 0.5502 \\
\hline & & $\mathrm{RW}^{*} \mathrm{~T}$ & 0.63 & 0.4334 & $\mathrm{H}^{* \mathrm{~T}}$ & 0.08 & 0.7844 & $\mathrm{RW} * \mathrm{~T}$ & 1.09 & 0.3024 & $\mathrm{H}^{*} \mathrm{~T}$ & 0.50 & 0.4835 \\
\hline & Maximum & RW & 62.41 & $<0.0001$ & $\mathrm{H}$ & 0.64 & 0.4293 & RW & 50.88 & $<0.0001$ & $\mathrm{H}$ & 8.14 & 0.0066 \\
\hline & & $\mathrm{T}$ & 0.68 & 0.4148 & $\mathrm{~T}$ & 1.50 & 0.2273 & $\mathrm{~T}$ & 1.64 & 0.2073 & $\mathrm{~T}$ & 0.16 & 0.6912 \\
\hline & & $\mathrm{RW}^{*} \mathrm{~T}$ & 0.87 & 0.3559 & $\mathrm{H}^{*} \mathrm{~T}$ & 0.18 & 0.6714 & $\mathrm{RW}^{*} \mathrm{~T}$ & 2.40 & 0.1284 & $\mathrm{H}^{* \mathrm{~T}}$ & 0.05 & 0.8253 \\
\hline \multirow[t]{3}{*}{ Width } & Latewood & RW & 55.83 & $<0.0001$ & $\mathrm{H}$ & 1.38 & 0.2464 & RW & 133.17 & $<0.0001$ & $\mathrm{H}$ & 0.28 & 0.5974 \\
\hline & & $\mathrm{T}$ & 1.58 & 0.2153 & $\mathrm{~T}$ & 0.00 & 0.9543 & $\mathrm{~T}$ & 0.21 & 0.6521 & $\mathrm{~T}$ & 0.78 & 0.3818 \\
\hline & & $\mathrm{RW}^{*} \mathrm{~T}$ & 0.00 & 0.9562 & $\mathrm{H}^{* \mathrm{~T}}$ & 0.83 & 0.3668 & $\mathrm{RW} * \mathrm{~T}$ & 2.65 & 0.1110 & $\mathrm{H}^{* \mathrm{~T}}$ & 2.24 & 0.1420 \\
\hline \multirow[t]{6}{*}{ Lumen area } & Earlywood & RW & 20.58 & $<0.0001$ & $\mathrm{H}$ & 0.75 & 0.3902 & RW & 8.82 & 0.0048 & $\mathrm{H}$ & 74.95 & $<0.0001$ \\
\hline & & $\mathrm{T}$ & 6.97 & 0.0115 & $\mathrm{~T}$ & 8.68 & 0.0050 & $\mathrm{~T}$ & 90.15 & $<0.0001$ & $\mathrm{~T}$ & 31.89 & $<0.0001$ \\
\hline & & $\mathrm{RW}^{*} \mathrm{~T}$ & 0.49 & 0.4863 & $\mathrm{H}^{*} \mathrm{~T}$ & 1.59 & 0.2138 & $\mathrm{RW}^{*} \mathrm{~T}$ & 4.57 & 0.0381 & $\mathrm{H}^{*} \mathrm{~T}$ & 5.50 & 0.0233 \\
\hline & Latewood & RW & 22.66 & $<0.0001$ & $\mathrm{H}$ & 1.32 & 0.2569 & RW & 31.40 & $<0.0001$ & $\mathrm{H}$ & 7.09 & 0.0107 \\
\hline & & $\mathrm{T}$ & 3.46 & 0.0697 & $\mathrm{~T}$ & 1.38 & 0.2464 & $\mathrm{~T}$ & 14.86 & 0.0004 & $\mathrm{~T}$ & 7.15 & 0.0104 \\
\hline & & $\mathrm{RW}^{*} \mathrm{~T}$ & 0.22 & 0.6385 & $\mathrm{H}^{* \mathrm{~T}}$ & 0.90 & 0.3489 & $\mathrm{RW}^{*} \mathrm{~T}$ & 8.76 & 0.0049 & $\mathrm{H}^{* \mathrm{~T}}$ & 1.15 & 0.2886 \\
\hline \multirow[t]{6}{*}{ Cell-wall thickness } & Earlywood & RW & 3.38 & 0.0730 & $\mathrm{H}$ & 5.43 & 0.0243 & RW & 25.49 & $<0.0001$ & $\mathrm{H}$ & 0.06 & 0.8030 \\
\hline & & $\mathrm{T}$ & 1.77 & 0.1909 & $\mathrm{~T}$ & 0.17 & 0.6857 & $\mathrm{~T}$ & 0.14 & 0.7057 & $\mathrm{~T}$ & 5.59 & 0.0223 \\
\hline & & $\mathrm{RW}^{*} \mathrm{~T}$ & 2.97 & 0.0919 & $\mathrm{H}^{* \mathrm{~T}}$ & 0.01 & 0.9235 & $\mathrm{RW} * \mathrm{~T}$ & 0.00 & 0.9721 & $\mathrm{H}^{* \mathrm{~T}}$ & 0.18 & 0.6733 \\
\hline & Latewood & RW & 12.65 & 0.0009 & $\mathrm{H}$ & 5.06 & 0.0294 & RW & 22.74 & $<0.0001$ & $\mathrm{H}$ & 0.12 & 0.7305 \\
\hline & & $\mathrm{T}$ & 2.92 & 0.0947 & $\mathrm{~T}$ & 0.04 & 0.8436 & $\mathrm{~T}$ & 0.50 & 0.4817 & $\mathrm{~T}$ & 1.96 & 0.1682 \\
\hline & & $\mathrm{RW}^{*} \mathrm{~T}$ & 0.07 & 0.7988 & $\mathrm{H}^{* \mathrm{~T}}$ & 0.20 & 0.6563 & $\mathrm{RW} * \mathrm{~T}$ & 0.60 & 0.4439 & $\mathrm{H}^{*} \mathrm{~T}$ & 3.28 & 0.0769 \\
\hline \multirow[t]{3}{*}{ Tracheid length } & Ring & RW & 12.47 & 0.0010 & $\mathrm{H}$ & 12.38 & 0.0010 & RW & 1.32 & 0.2561 & $\mathrm{H}$ & 102.07 & $<0.0001$ \\
\hline & & $\mathrm{T}$ & 6.81 & 0.0125 & $\mathrm{~T}$ & 0.11 & 0.7411 & $\mathrm{~T}$ & 55.76 & $<0.0001$ & $\mathrm{~T}$ & 4.77 & 0.0341 \\
\hline & & $\mathrm{RW}^{*} \mathrm{~T}$ & 0.00 & 0.9633 & $\mathrm{H}^{* \mathrm{~T}}$ & 0.35 & 0.5553 & $\mathrm{RW}^{*} \mathrm{~T}$ & 0.57 & 0.4550 & $\mathrm{H}^{*} \mathrm{~T}$ & 1.61 & 0.2106 \\
\hline
\end{tabular}

Significant values are in italics

\section{Discussion}

\subsection{Unmanaged plots}

Our hypothesis of a stronger relationship between wood properties and ring width in trees from even-aged plots compared to uneven-aged plots was rejected (Fig. 2, Table 3). Of the ten wood properties measured in our study, eight were correlated with ring width independently of stand structure. Ring density was not correlated to ring width, because earlywood and latewood density decreased and increased, respectively, with ring width. Increased radial growth is usually associated with a decrease in average ring density (e.g., Mäkinen et al. 2002b; Xiang et al. 2014), following reductions in latewood proportion (Wang et al. 2002; Zhang 1998). Latewood density, latewood width, and wall thickness increased with radial growth, thus increasing the stability of the tree (Pallardy and Kozlowski 2008). Larger lumen areas were observed at increased ring widths, resulting in a decrease in earlywood density and lower cavitation resistance (Dalla-Salda et al. 2009).

We observed significant differences in ring width between even-aged and uneven-aged stands. Earlywood lumen area and tracheid length differed between the even-aged and uneven-aged stands (Fig. 2, Table 3). This difference is explained by the tree height within uneven-aged stands. Taller trees need a greater hydraulic conductivity to transfer water from their roots to their needles. A larger lumen area observed in the even-aged stands achieves this aim, as a larger lumen area enhances the efficiency of water transport (Gebhardt et al. 2014; Boczon et al. 2016). Earlywood lumen area decreased 
Ring
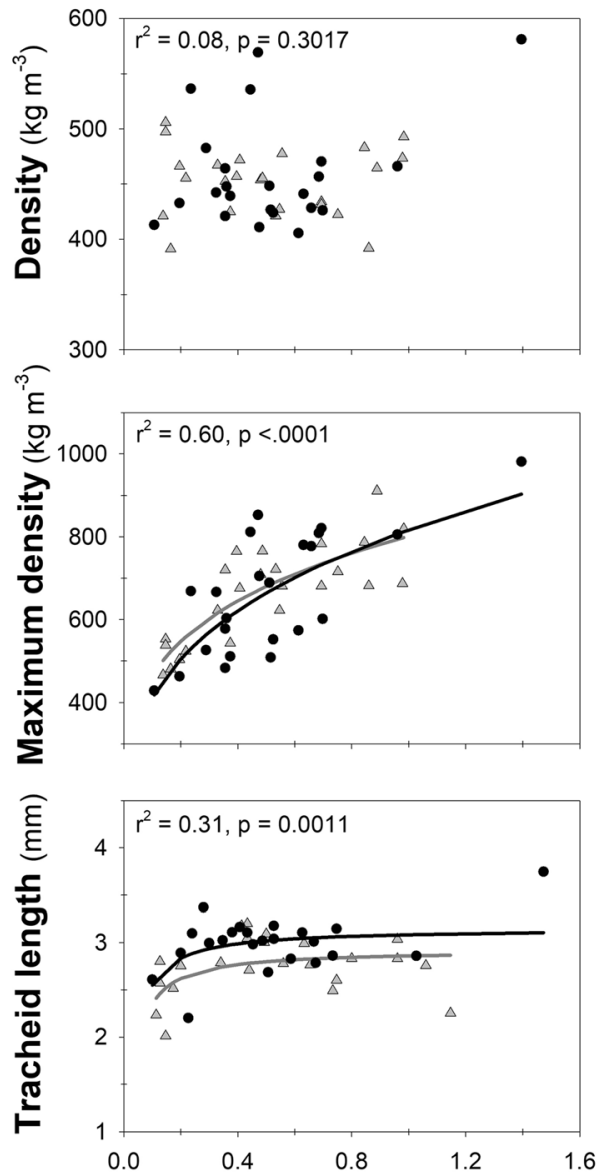

Ring width (mm)

Even-aged plots

- Measured values

Predicted values

\section{Uneven-aged plots}

$\triangle \quad$ Measured values

Predicted values
Earlywood
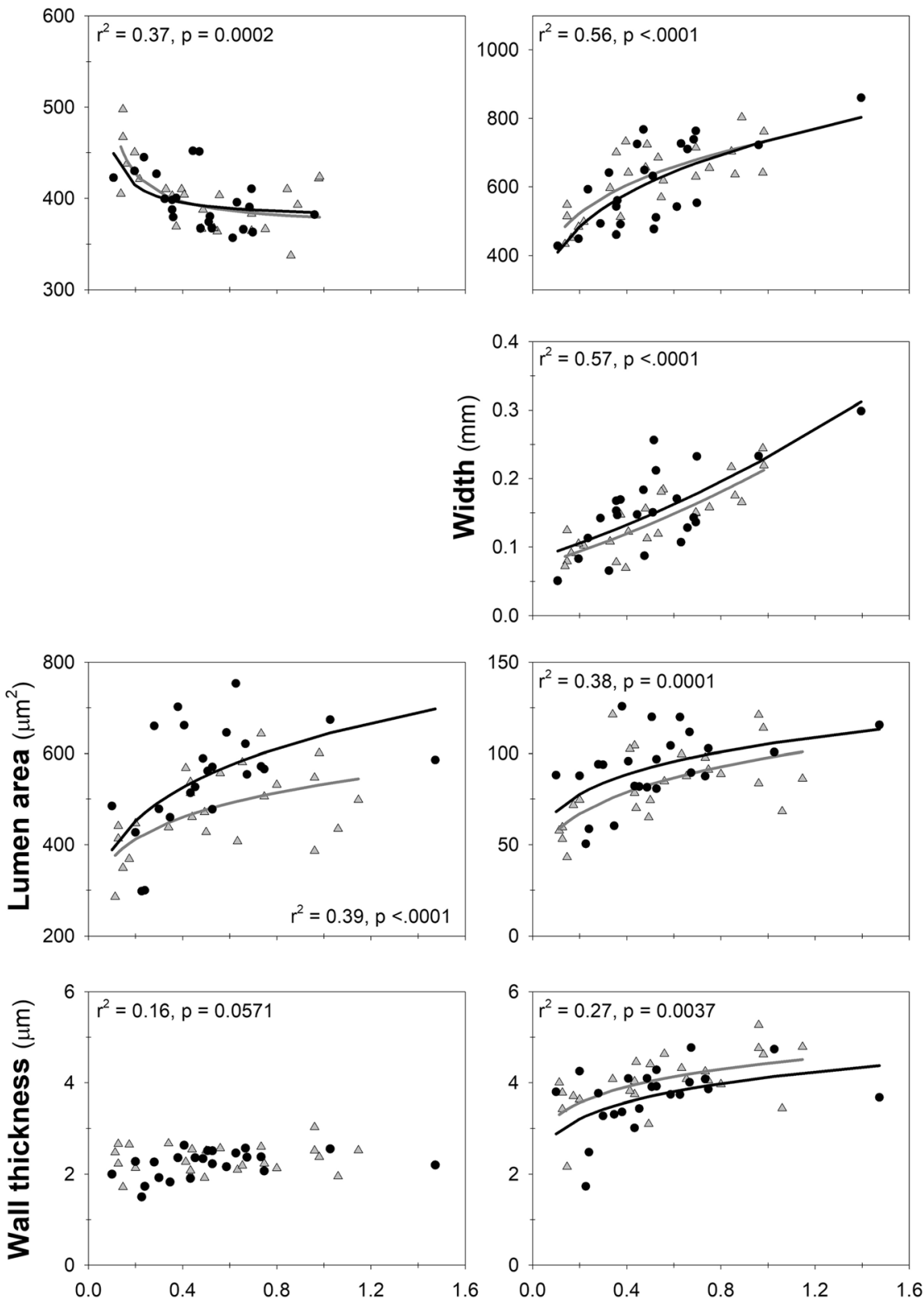

Ring width (mm)

Fig. 2 The relationship between wood properties and ring width of black spruce in even-aged (black) and uneven-aged (gray) unmanaged plots. Predicted values are presented only when the model is significant $(p<0.05)$

proportionally with stem height in the even-aged stands and increased slightly in the uneven-aged stands without any changes in wall thickness. A similar pattern was observed by Anfodillo et al. (2012) and expected to be related to the possible increase in the total hydraulic resistance within the tree.

Tracheid length increased with ring width in both stand structures. A significant increase was observed at smaller ring widths $(<0.4 \mathrm{~mm})$, whereas similar values were found within the larger tree rings. Vysotsaya and Vaganov (1989) stated that the lack of variation in cell dimension occurs only for ring widths $>0.5 \mathrm{~mm}$. Even if we did not observe this limit for our black spruce samples, it is likely that above a certain ring width, limiting factors (e.g., water availability) restrain production, enlargement, and elongation of xylem cells.

\subsection{Managed plots}

Managed plots exhibited an interaction ring width $\times$ stand structure for lumen area and earlywood density, a pattern absent in unmanaged stands. Earlywood and latewood lumen areas increased with ring width in unmanaged even-aged plots, whereas this pattern was not observed in the managed 
Ring

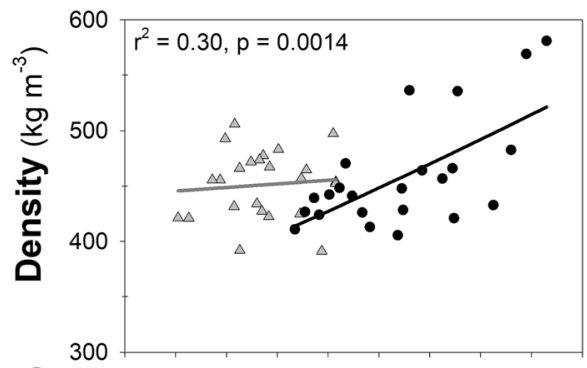$$
\text { ? }
$$
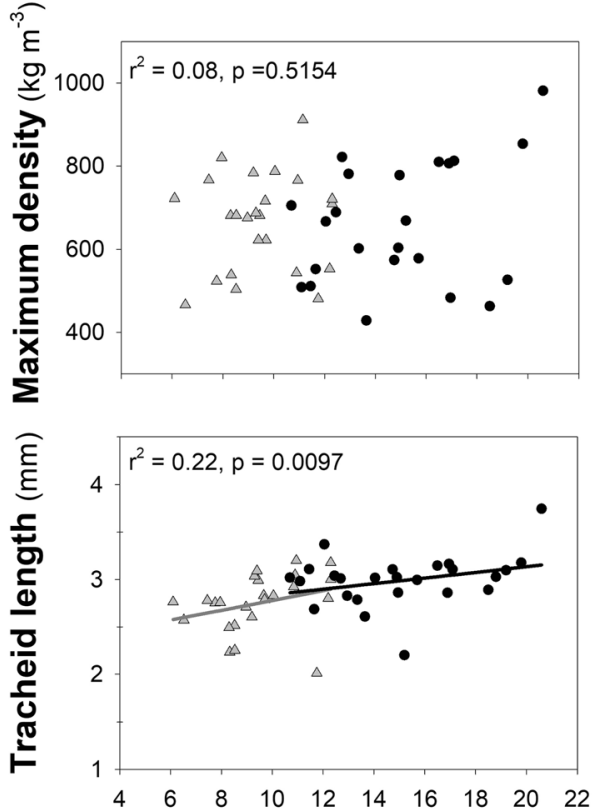

Tree height $(\mathrm{m})$

Even-aged plots

- Measured values

_ Predicted values

Uneven-aged plots

$\Delta \quad$ Measured values Predicted values
Earlywood
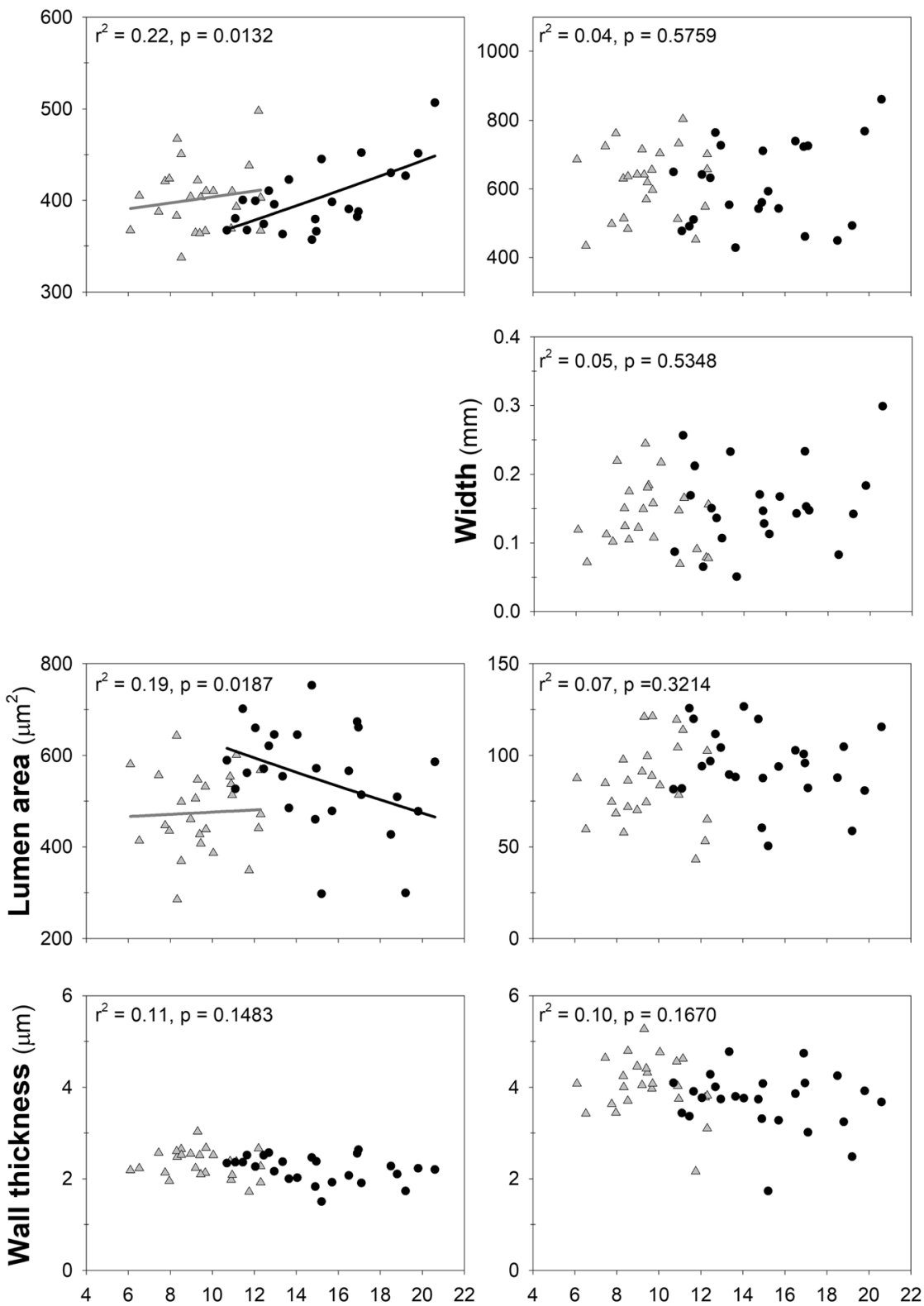

Tree height $(\mathrm{m})$

Fig. 3 The relationship between wood properties and tree height of black spruce in even-aged (black) and uneven-aged (gray) unmanaged plots. Predicted values are presented only when the model is significant $(p<0.05)$

plots (Fig. 4). This observation supported our second hypothesis that partial cutting alters the relationship between wood properties and ring width.

Ring width was larger in plots subjected to partial cutting (Table 2), with large radial cell productions in trees of evenaged plots. In these managed plots, lumen area in earlywood and latewood was ca. 600 and $110 \mu \mathrm{m}^{2}$, respectively. Partial cutting increased lumen areas in latewood of black spruce (Krause et al. 2011) and other boreal species (Mäkinen et al. $2002 b)$. Lumen area is a function of tree water status at the time of cell formation (Fonti and Jansen 2012). The lack of variation in lumen area in even-aged stands can be explained by the tree status prior to and after cutting. Commercial thinning from below keeps the dominant trees in the stand (Doucet et al. 2009). The residual trees already have the structural attributes (roots and foliage) necessary to benefit from the increase in water availability flowing the thinning (Fayle 1983). Lumen area of black spruce expands until it reaches a limit above which the risk of freeze-thaw embolism is too high. In conifers, there is a threshold of $30 \mu \mathrm{m}$ in lumen diameter, above which the risk of freeze-thaw embolism increases abruptly (Pittermann and Sperry 2003). The mean 
Ring
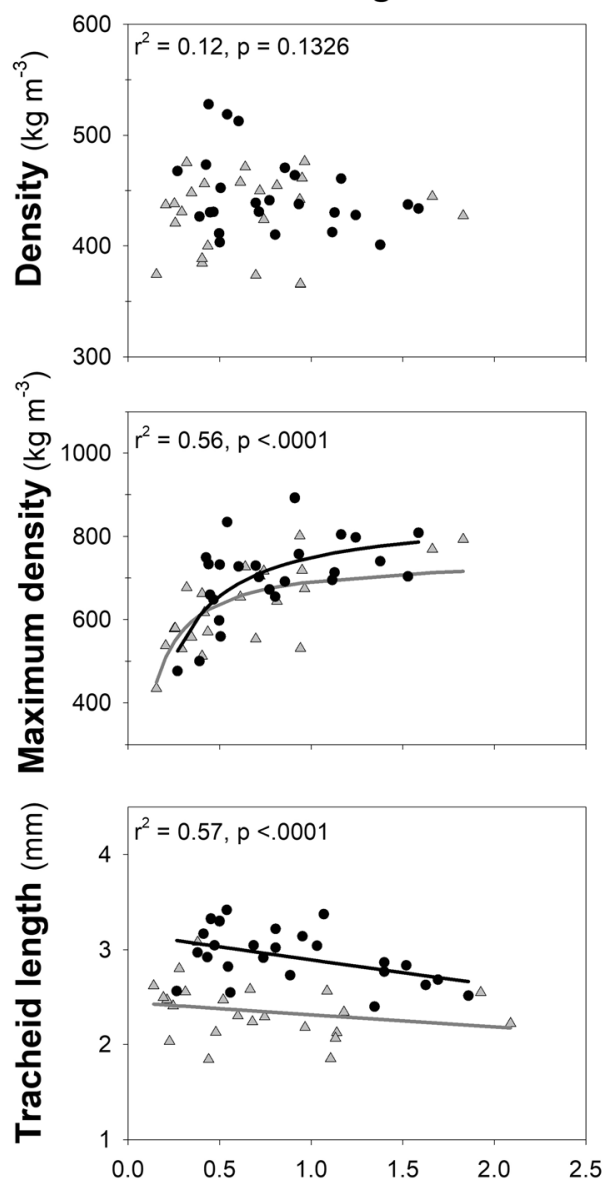

Ring width $(\mathrm{mm})$

Even-aged plots

- Measured values

Predicted values

Uneven-aged plots

$\triangle \quad$ Measured values

- Predicted values
Earlywood
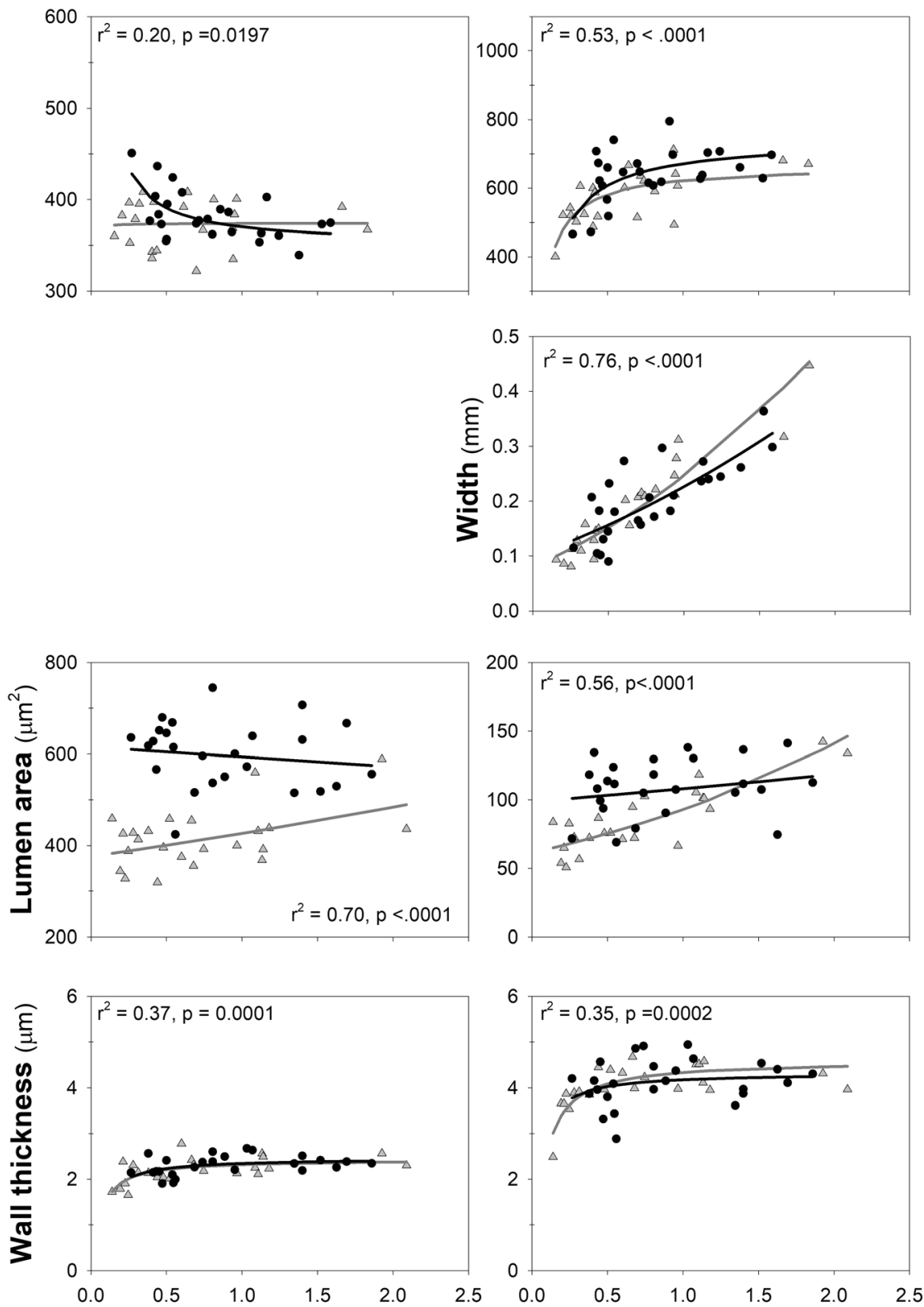

Ring width $(\mathrm{mm})$

Fig. 4 The relationship between wood properties and ring width of black spruce after a partial-cutting treatment in even-aged (black) and uneven-aged (gray) managed plots. Predicted values are presented only when the model is significant $(p<0.05)$

tracheid diameter of residual trees after partial cutting in evenaged plots was $28 \mu \mathrm{m}$, which confirmed the freeze-thaw threshold proposed by Pittermann and Sperry (2003). One mechanism to reduce the risk of cavitation is to form smaller tracheids having thicker cell walls (Dutilleul et al. 1998; Mäkinen et al. 2007), as observed in the residual trees of our study. Hence, even for uneven-aged stands, lumen area should not exceed this threshold; as such, wood density would not decrease below the values observed in our study.

Cell-wall thickness increased in earlywood and latewood with tree-ring width for both even-aged and uneven-aged plots (Fig. 4; Table 3). This increase may be responsible for the observed increase in latewood density and explain the lack of variation in earlywood density after partial cutting in uneven-aged plots. Warmer conditions can result in larger tree-ring widths (Gričar et al. 2005; Rossi et al. 2006). Temperature also controls sugar availability (Begum et al. 2013; Schmitt et al. 2004), and consequently cell-wall thickness (Vaganov et al. 2006). Furthermore, as soil temperature increases after a partial cutting (Thibodeau et al. 2000), a lengthening of the period of xylem growth can be expected (Lupi et al. 2012). Thus, more time is allocated to 
xylem cell maturation, which could produce wider lumen areas and thicker cell walls (Rossi et al. 2011). After a partial cutting, stand density is reduced, thereby increasing snow cover on the ground and reducing the depth of soil frost (Löfvnius et al. 2003). Moreover, the increase in solar radiation speeds up snowmelt and soil warming in early spring (Davis et al. 1997; Löfvnius et al. 2003; Prévost and Raymond 2012). We raise the hypothesis that an early soil warming influences earlywood cell-wall thickness. This result is important as wood density would not be as negatively affected by partial cutting as previously thought, since wood density increases with increased wall thickness.

Ring density was not correlated with ring width even after partial cutting. Vincent et al. (2011) reported a nonsignificant decrease in the ring density of black spruce after commercial thinning. Peltola et al. (2007) and Mäkinen and Hynynen (2014) also found limited changes in the wood density of Scots pine after thinning despite a significant increase in radial growth. For unmanaged and managed plots, the average wood density $(430-459 \mathrm{~kg}$
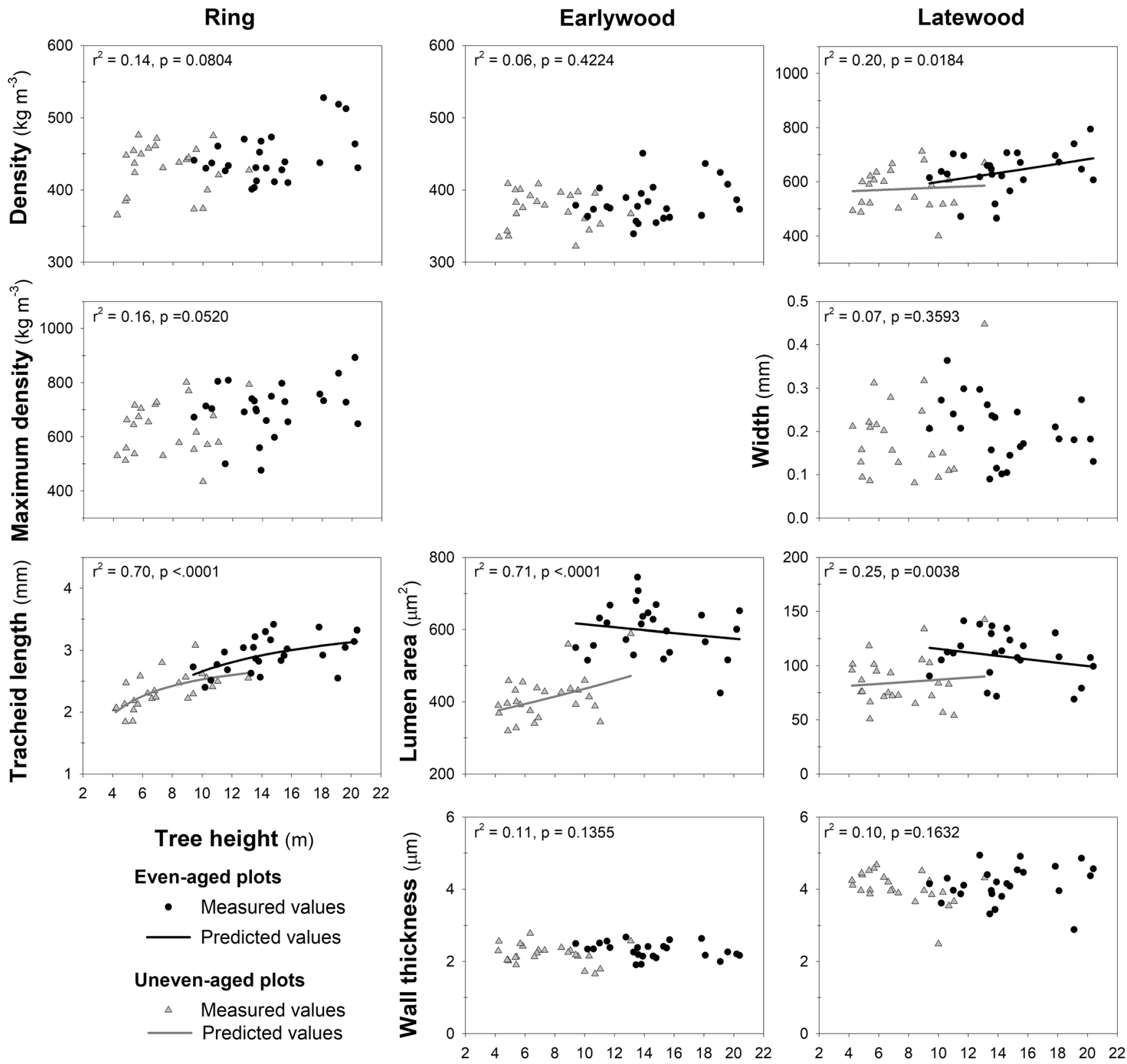

\section{Tree height $(\mathrm{m})$}

Fig. 5 The relationship between wood properties and tree height of black spruce after a partial-cutting treatment in even-aged (black) and uneven-aged (gray) managed plots. Predicted values are presented only when the model is significant $(p<0.05)$ 
$\mathrm{m}^{-3}$ ) fell in the same range previously observed in North America (363-455 $\mathrm{kg} \mathrm{m}^{-3}$ ) (Zhang and Koubaa 2008).

The lack of variation in ring density can be explained by a significant decrease in earlywood density combined with an increase in latewood density as tree-ring width increased for even-aged stands (Fig. 4; Table 3). Average ring density is often described as a proxy of wood quality in terms of mechanical properties (Alteyrac et al. 2006; Panshin and Zeeuw 1980). The significant difference in density between earlywood and latewood in even-aged managed stands results in a wood heterogeneity that could be detrimental to forest industry (Shmulsky and Jones 2011).

Ring density and tracheid length were correlated to tree height in managed plots (Table 4, Fig. 5). Different relationships were observed between even-aged and uneven-aged plots for earlywood and latewood lumen area and tracheid length. Compared to uneven-aged plots, both managed and unmanaged even-aged plots exhibited wider lumen areas and longer tracheid lengths. The difference in tree height and crown length between stand structures may have played a significant role as higher crown ratios are associated to trees with longer and larger branches (Pretzsch and Rais 2016). Buds and the developing leaves are a major source of auxin, which increases cell differentiation and limits the time for enlargement (Aloni and Zimmermann 1983). Therefore, if two trees are sampled at the same height, smaller trees are expected to have smaller lumen areas (Anfodillo et al. 2006). This was the case for trees from the uneven-aged plots in our study.

\section{Conclusion}

Overall, almost all measured wood properties were correlated to ring width, and we observed few differences in wood properties between the even- and uneven-aged unmanaged plots. A greater number of significant correlations between ring width and the two forest types were observed in those plots submitted to partial cutting. Several wood properties (ring wood and earlywood density, tracheid length, and cell-wall thickness in both earlywood and latewood) were also correlated with tree height with some significant differences between forest types. Increased ring width had no impact on wood density as both earlywood width and density decreased, while latewood width and density increased. The same observation was also observed after partial cutting. Thus, the increased growth after partial cutting has a limited influence on wood quality and, as such, limits the practical implications for forest management. Even with several significant differences between even- and uneven-aged stands, the influences of tree-ring width and tree height on wood quality were quite limited; this observation restrains the use of tree-ring width and tree height in large-scale models. Climate conditions, stand density, and tree social status are likely better indicators of wood characteristics; therefore, a greater investment should be directed toward evaluating the relationships between those factors and wood quality.

Acknowledgments We thank those who were involved in the field and laboratory work: Benoit Allaire, Mireille Boulianne, Charles-Augustin Dery Bouchard, Isabelle Grenon, Winna Landry, Maxime Larouche, Pierre-Yves Plourde, Germain Savard, Maxime Tremblay, and Manon Vincent. We thank Murray Hay for the language revision of the manuscript.

Author's Contributions Experimental design: EPC, CK, DP; data analysis: EPC SR; first draft: EPC; final writing: all authors; supervision: CK, $\mathrm{DP}$; funding acquisition: $\mathrm{CK}$

Funding This work was supported by the Natural Sciences and Engineering Research Council of Canada (NSERC) and the Fonds de Recherche du Québec - Nature et Technologies (FQRNT).

Data availability The datasets generated and/or analyzed during the current study are available from the authors on reasonable request.

\section{Compliance with ethical standards}

Conflict of interest The authors declare that they have no conflict of interest.

\section{References}

Aloni R, Zimmermann MH (1983) The control of vessel size and density along the plant axis : a new hypothesis. Differentiation 24:203-208. https://doi.org/10.1111/j.1432-0436.1983.tb01320.x

Alteyrac J, Zhang SY, Cloutier A, Ruel JC (2005) Influence of stand density on ring width and wood denisity at different sampling heights in black spruce (Picea mariana (Mill.) BSP). Wood Fiber Sci 37:83-94

Alteyrac J, Cloutier A, Ung CH, Zhang SY (2006) Mechanical properties in relation to selected wood characteristics of black spruce. Wood Fiber Sci 38:229-237

Anfodillo T, Carraro V, Carrer M, Fior C, Rossi S (2006) Convergent tapering of xylem conduits in different woody species. New Phytol 169:279-290. https://doi.org/10.1111/j.1469-8137.2005.01587.x

Anfodillo T, Deslauriers A, Menardi R, Tedoldi L, Petit G, Rossi S (2012) Widening of xylem conduits in a conifer tree depends on the longer time of cell expansion downwards along the stem. 63:837-845

Begum S, Nakaba S, Yamagishi Y, Oribe Y, Funada R (2013) Regulation of cambial activity in relation to environmental conditions: understanding the role of temperature in wood formation of trees. Physiol Plant 147:46-54. https://doi.org/10.1111/j.1399-3054.2012.01663.x

Bergeron Y, Harvey B, Leduc A, Gauthier S (1999) Forest management guidelines based on natural disturbance dynamics: stand- and forestlevel considerations. For Chron 75:49-54. https://doi.org/10.5558/ tfc75049-1

Bouchard M, Pothier D, Gauthier S (2008) Fire return intervals and tree species succession in the North Shore region of eastern Quebec. Can J For Res-Rev Can Rech For 38:1621-1633. https://doi.org/10. 1139/x07-201 
Boucher D, De Grandpré L, Gauthier S (2003) Development of a stand structure classification systems and comparison of two lichen-spruce woodlands in Quebec. For Chron 79:318-328

Bouslimi B, Koubaa A, Bergeron Y (2014) Anatomical properties in Thuja occidentalis: variation and relationship to biological processes. IAWA J 35:363-384. https://doi.org/10.1163/2294193200000072

Claveau Y, Messier C, Comeau PG, Coates KD (2002) Growth and crown morphological responses of boreal conifer seedlings and saplings with contrasting shade tolerance to a gradient of light and height. 32:458-468. https://doi.org/10.1139/x01-220

Côté G, Bouchard M, Pothier D, Gauthier S (2010) Linking stand attributes to cartographic information for ecosystem management purposes in the boreal forest of eastern Quebec. For Chron 86:511-519

Dalla-Salda G, Martinez-Meier A, Cochard H, Rozenberg P (2009) Variation of wood density and hydraulic properties of Douglas-fir (Pseudotsuga menziesii (Mirb.) Franco) clones related to a heat and drought wave in France. For Ecol Manag 257:182-189. https://doi. org/10.1016/j.foreco.2008.08.019

Davis RE, Hardy JP, Ni W, Woodcock C, Mckenzie JC, Jordan R, Li X (1997) Variation of snow cover ablation in the boreal forest: a sensitivity study on the effects of conifer canopy. J Geophys Res Atmos 102:29389-29395. https://doi.org/10.1029/97jd01335

Denne MP (1988) Definition of latewood according to Mork (1928). IAWA J 10:59-62. https://doi.org/10.1163/22941932-90001112

Deslauriers A (1999) Mise en place du cerne de croissance chez le sapin baumier (Abies balsamea (L.) Mill.) Dissertation Université du Québec à Chicoutimi

Deslauriers A, Morin H, Begin Y (2003) Cellular phenology of annual ring formation of Abies balsamea in the Quebec boreal forest (Canada). Can J For Res 33:190-200. https://doi.org/10.1139/x02-178

Doucet R, Ruel J-C, Jutras S, Lessard G, Pineau M, Prégent G, Thiffault N (2009) La sylviculture appliquée. In: Ouvrage collectif ÉM (ed) Ordre des ingénieures forestiers du Québec, Manuel de Foresterie, 2nd edn, Québec, pp 1149-1186

Dutilleul P, Herman M, Avella-Shaw T (1998) Growth rate effects on correlations among ring width, wood density, and mean tracheid length in Norway spruce (Picea abies). Can J For Res 28:56-68. https://doi.org/10.1139/x97-189

Fayle DCF (1983) Differences between stem and root thickening at their junction in red pine. Plant Soil 71:161-166. https://doi.org/10.1007/ 978-94-009-6833-2 16

Fernandez ME, Gyenge GE, de Urquiza MM (2012) Varela S, Adaptability to climate change in forestry species: drought effects on growth and wood anatomy of ponderosa pines growing at different competition levels. 21:162-173

Fonti P, Jansen S (2012) Xylem plasticity in response to climate. New Phytol 195:734-736. https://doi.org/10.1111/j.1469-8137.2012. 04252.x

Franklin GL (1945) Preparation of thin sections of synthetic resins and wood-resin composites, and a new macerating method for wood. Nature 155:51-51. https://doi.org/10.1038/155051a0

Gebhardt T, Häberle KH, Matyssek R, Schulz C, Ammer C (2014) The more, the better? Water relations of Norway spruce stands after progressive thinning. Agric For Meterol 197:235-243 https://doi. org/10.1016/j.agrformet.2014.05.013

Gričar J, Čufar K, Oven P, Schmitt U (2005) Differentiation of terminal latewood tracheids in silver fir trees during autumn. Ann Bot 95: 959-965. https://doi.org/10.1093/aob/mci112

Harper KA, Bergeron Y, Drapeau P, Gauthier S, De Grandpré L (2006) Changes in spatial pattern of trees and snags during structural development in Picea mariana boreal forests. J Veg Sci 17:625-636. https://doi.org/10.1111/j.1654-1103.2006.tb02486.x

Hunter MLJ (1990) Wildlife, forest and forestry: principles of managing forests for biological diversity. Prentice-Hall, Englewood Cliffs, NJ
Koubaa A, Zhang SY, Isabel N, Beaulieu J, Bousquet J (2000) Phenotypic correlations between juvenile-mature wood density and growth in black spruce. Wood Fiber Sci 32:61-71

Koubaa A, Zhang SY, Makni S (2002) Defining the transition from earlywood to latewood in black spruce based on intra-ring wood density profiles from X-ray densitometry. Ann For Sci 59:511-518. https://doi.org/10.1051/forest:2002035

Krause C, Rossi S, Thibeault-Martel M, Plourde PY (2010) Relationships of climate and cell features in stems and roots of black spruce and balsam fir. Ann For Sci 67:402-402. https://doi.org/10.1051/forest/ 2009122

Krause C, Laplante S, Plourde PY (2011) Transversal tracheid dimension in thinned black spruce and Jack pine stands in the boreal forest. Scand J For Res 26:477-487. https://doi.org/10.1080/02827581. 2011.579995

Lenz P, Deslauriers M, Ung C-H, MacKay J, Beaulieu J (2014) What do ecological regions tell us about wood quality? A case study in eastern Canadian white spruce 44:1383-1393. https://doi.org/10.1139/ cjfr-2014-0206

Liu C, Ruel JC, Zhang SY (2007) Immediate impacts of partial cutting strategies on stand characteristics and value. For Ecol Manag 250: 148-155. https://doi.org/10.1016/j.foreco.2007.05.010

Löfvnius MO, Kluge M, Lundmark T (2003) Snow and soil frost depth in two types of shelterwood and a clear-cut area. Scand J For Res 18: 54-63. https://doi.org/10.1080/0891060310002345

Lovisolo C, Schubert A, Sorce C (2002) Are xylem radial development and hydraulic conductivity in downwardly-growing grapevine shoots influenced by perturbed auxin metabolism? New Phytol 156:65-74. https://doi.org/10.1046/j.1469-8137.2002.00492.x

Lupi C, Morin H, Deslauriers A, Rossi S, Houle D (2012) Increasing nitrogen availability and soil temperature: effects on xylem phenology and anatomy of mature black spruce. $42: 1277-1288 \mathrm{https}: / /$ doi. org/10.1139/x2012-055

Mäkinen H, Hynynen J (2014) Wood density and tracheid properties of Scots pine: responses to repeated fertilization and timing of the first commercial thinning. Forestry 87:437-447. https://doi.org/10.1093/ forestry/cpu004

Mäkinen H, Saranpää P, Linder S (2002a) Effect of growth rate on fibre characteristics in Norway spruce (Picea abies (L.) Karst.). Holzforschung 56:449-460. https://doi.org/10.1515/hf.2002.070

Mäkinen H, Saranpää P, Linder S (2002b) Wood-density variation of Norway spruce in relation to nutrient optimization and fibre dimensions. Can J For Res 32:185-194. https://doi.org/10.1139/x01-186

Mäkinen H, Jaakkola T, Piispanen R, Saranpää P (2007) Predicting wood and tracheid properties of Norway spruce. For Ecol Manag 241: 175-188. https://doi.org/10.1016/j.foreco.2007.01.017

Pallardy SG, Kozlowski TT (2008) Physiology of woody plants. Elsevier, Amsterdam

Pamerleau-Couture É, Krause C, Pothier D, Weiskittel A (2015) Effect of three partial cutting practices on stand structure and growth of residual black spruce trees in north-eastern Quebec. Forestry 88:471483. https://doi.org/10.1093/forestry/cpv017

Panshin AJ, Zeeuw C (1980) Textbook of wood technology, 4th edn. McGraw-Hill, New-York

Peltola H, Kilpelainen A, Sauvala K, Raisanen T, Ikonen VP (2007) Effects of early thinning regime and tree status on the radial growth and wood density of Scots pine. Silva Fenn 41:489-505. https://doi. org/10.14214/sf.285

Pham AT, De Grandpré L, Gauthier S, Bergeron Y (2004) Gap dynamics and replacement patterns in gaps of the northeastern boreal forest of Quebec. Can J For Res 34:353-364. https://doi.org/10.1139/x03-265

Philip MS (1994) Measuring trees and forests, 2nd edn. CAB international, Wallington

Piispanen R, Heinonen J, Valkonen S, Mäkinen H, Lundqvist SO, Saranpaa P (2014) Wood density of Norway spruce in uneven- 
aged stands. Can J For Res 44:136-144. https://doi.org/10.1139/cjfr2013-0201

Pittermann J, Sperry J (2003) Tracheid diameter is the key trait determining the extent of freezing-induced embolism in conifers. Tree Physiol 23:907-914. https://doi.org/10.1093/treephys/23.13.907

Pretzsch H, Rais A (2016) Wood quality in complex forests versus evenaged monocultures: review and perspectives. Wood Sci Technol 50: 845-880. https://doi.org/10.1007/s00226-016-0827-z

Prévost M, Raymond P (2012) Effect of gap size, aspect and slope on available light and soil temperature after patch-selection in yellow birch-conifer stands, Quebec, Canada. For Ecol Manag 274:210 221. https://doi.org/10.1016/j.foreco.2012.02.020

Raulier F, Pothier D, Bernier PY (2003) Predicting the effect of thinning on growth of dense balsam fir stands using a process-based tree growth model. Can J For Res 33:509-520.https://doi.org/10.1139/ x03-009

Raven PH, Eichhorn SE, Bouharmont J, Evert RF (2000) Biologie végétale, 6th edn. De Boeck Université, Paris

Rossi S, Deslauriers A, Anfodillo T (2006) Assessment of cambial activity and xylogenesis by microsampling tree species: an example at the Alpine timberline. IAWA J 27:383-394. https://doi.org/10.1163/ 22941932-90000161

Rossi S, Tremblay MJ, Morin H, Levasseur V (2009) Stand structure and dynamics of Picea mariana on the northern border of the natural closed boreal forest in Quebec, Canada. Can J For Res-Rev Can Rech For 39:2307-2318. https://doi.org/10.1139/x09-152

Rossi S, Morin H, Deslauriers A, Plourde PY (2011) Predicting xylem phenology in black spruce under climate warming. Glob Chang Biol 17:614-625. https://doi.org/10.1111/j.1365-2486.2010.02191.x

Saranpää P (2003) Wood density and growth. In: Barnett JR, Jeronimidis G (eds) Wood quality and its biological basis. Blackwell \& CRC Press, Oxford, Boca Raton, pp 87-117

Schmitt U, Jalkanen R, Eckstein D (2004) Cambium dynamics of Pinus sylvestris and Betula spp. in the northern boreal forest in Finland. Silva Fenn 38:167-178. https://doi.org/10.14214/sf.426

Shmulsky R, Jones PD (2011) Forest products and wood science, 6th edn. Wiley-Blackwell, Ames

St-Pierre H, Gagnon R, Bellefleur P (1991) Distribution spatiale de la régénération après feu de l'épinette noire (Picea mariana) et du pin gris (Pinus banksiana) dans la forêt boréale, Réserve faunique Ashuapmushuan. Québec. 69:717-721

Tardif J, Bergeron Y (1993) Radial growth of Fraxinus nigra in a Canadian boreal forest floodplain in response to climate and hydrological fluctuation. J Veg Sci 4:751-758. https://oi.org/10.2307/ 3235611

Thibodeau L, Raymond P, Camire C, Munson AD (2000) Impact of precommercial thinning in balsam fir stands on soil nitrogen dynamics, microbial biomass, decomposition, and foliar nutrition. Can J For Res 30:229-238. https://doi.org/10.1139/x99-202
Torquato LP, Auty D, Hernandez RE, Duchesne I, Pothier D, Achim A (2014) Black spruce trees from fire-origin stands have higher wood mechanical properties than those from older, irregular stands. Can J For Res-Rev Can Rech For 44:118-127. https://doi.org/10.1139/ cjfr-2013-0164

Vaganov EA (1990) The tracheidogram method in tree-ring analysis and its application. In: Cook ER, Kairiukstis LA (eds) Methods of dendrochronology: applications in the environmental sciences. Kluwer Academy Publishers, Drodrecht, pp 63-76

Vaganov EA, Hughes MK, Shashkin AV (2006) Growth dynamics of conifer tree rings: images of past and future environments. Springer, Berlin

Viereck LA, Johnston WF (1990) Picea mariana (Mill.) B.S.P. Black spruce. In: Burns RM, Honkala BH (eds) Silvics of North America, 1. Conifers, Agriculture Handbook No. 654. USDA Forest Service, Washington, DC

Vincent M, Krause C, Zhang SY (2009) Radial growth response of black spruce roots and stems to commercial thinning in the boreal forest. Forestry 82:557-571. https://doi.org/10.1093/forestry/cpp025

Vincent M, Krause C, Koubaa A (2011) Variation in black spruce (Picea mariana (Mill.) BSP) wood quality after thinning. Ann For Sci 68: 1115-1125. https://doi.org/10.1007/s13595-011-0127-6

Vysotsaya LG, Vaganov EA (1989) Components of the variability of radial cell size in tree rings of conifers. IAWA J 10:417-426. https://doi.org/10.1163/22941932-90001134

Wang L, Payette S, Bégin Y (2002) Relationships between anatomical and densitometric characteristics of black spruce and summer temperature at tree line in northern Quebec. Can J For Res 32:477-486. https://doi.org/10.1139/x01-208

Weetman GF (1975) Ten-year growth response of black spruce to thinning and fertilization treatments. Can J For Res 5:302-309. https:// doi.org/10.1139/x75-041

Xiang W, Leitch M, Auty D, Duchateau E, Achim A (2014) Radial trends in black spruce wood density can show an age- and growth-related decline. Ann For Sci 71:603-615. https://doi.org/10.1007/s13595014-0363-7

Zhang SY (1998) Effect of age on the variation, correlations and inheritance of selected wood characteristics in black spruce (Picea mariana). Wood Sci Technol 32:197-204. https://doi.org/10.1007/ bf00704842

Zhang SY, Koubaa A (2008) Softwoods of Eastern Canada: their silvics, characteristics, manufacturing and end-uses. FPInnovations, Québec

Publisher's note Springer Nature remains neutral with regard to jurisdictional claims in published maps and institutional affiliations. 